\title{
PEACE EDUCATION
}

\author{
Oleh: Abas Yusuf ${ }^{1}$
}

\begin{abstract}
Abstrak: Tantangan dalam dunia pendidikan adalah bagaimana caranya agar budaya ini dapat dipelajari dan diajarkan. Pertanyaan yang harus dijawab oleh para pendidik intelektual adalah: bagaimana seseorang dapat mempelajari sikap dan perilaku yang selaras dengan budaya perdamaian? Berdasarkan pengalaman beberapa negara rawan konflik yang mencoba menjawab pertanyaan ini, jawabannya tidaklah sederhana. Faktor-faktor yang terlibat tidak sekedar kognisi dan emosi yang menjadi lahan garapan para pendidik, melainkan meluas ke faktor-faktor politik, ekonomi, dan sosial budaya yang seringkali terbentuk dari akar sejarah yang panjang.
\end{abstract}

\section{Kata-kata Kunci}

\section{Upaya Global Dalam Mewujudkan Budaya Perdamaian}

Pada masa Perang Dunia II, kalangan internasional mulai menyadari pentingnya mengupayakan keamanan dan perdamaian dunia secara aktif dalam sebuah payung organisasi berskala dunia. Untuk itu, dibentuklah UNESCO pada tahun 1945, sebuah badan PBB yang bertujuan mengupayakan keamanan dan perdamaian melalui pendidikan, keilmuan, dan kebudayaan. Dalam perkembangannya, muncul sebuah gagasan untuk mewujudkan a culture of peace (budaya perdamaian) dalam sebuah kongres internasional di Yamoussoukro pada tahun 1989. Gagasan ini dikembangkan lebih jauh dalam sebuah Konferensi Internasional Pendidikan ke-44 pada tahun 1994, dan saat ini telah menjadi salah satu strategi utama yang diusung UNESCO.

Berbeda dengan budaya perang (a culture of war) yang menggunakan kekerasan untuk mengatasi konflik, budaya perdamaian menggunakan jalur dialog dan mediasi. Budaya perdamaian memiliki sebuah prinsip, bahwa manusia memiliki hak dan martabat yang sama, meskipun berbeda jenis kelamin, ras, suku, agama, ataupun

\footnotetext{
${ }^{1}$ Abas Yusuf adalah dosen Jurusan Ilmu Pendidikan FKIP-UNTAN Pontianak.
} 
kewarganegaraan. Budaya ini menginspirasi manusia untuk saling menghargai kehidupan, menghargai sesama sebagai seorang manusia, dan menghargai hak dan martabatnya. Budaya perdamaian menolak segala bentuk kekerasan, dan berkomitmen pada prinsip kebebasan, keadilan, solidaritas, toleransi, dan saling pengertian. Budaya ini percaya bahwa perang dan kekerasan bukan satu-satunya jalan untuk mengatasi perbedaan, bahwa mendapatkan keinginan tidak berarti harus membuat orang lain kehilangan. Jika perdamaian lebih membawa kebaikan, maka ia layak diperjuangkan.

Tantangan dalam dunia pendidikan adalah bagaimana caranya agar budaya ini dapat dipelajari dan diajarkan. Pertanyaan yang harus dijawab oleh para pendidik intelektual adalah: bagaimana seseorang dapat mempelajari sikap dan perilaku yang selaras dengan budaya perdamaian? Bagaimanakah caranya agar kita dapat belajar untuk hidup saling berdampingan? Berdasarkan pengalaman beberapa negara rawan konflik yang mencoba menjawab pertanyaan ini, jawabannya tidaklah sederhana. Faktor-faktor yang terlibat tidak sekedar kognisi dan emosi yang menjadi lahan garapan para pendidik, melainkan meluas ke faktor-faktor politik, ekonomi, dan sosial budaya yang seringkali terbentuk dari akar sejarah yang panjang. Namun, meskipun tidak mudah, mempelajari dan mengajarkan budaya perdamaian adalah tanggung jawab kita bersama sebagai seorang pendidik. Meskipun sulit, jika perdamaian lebih membawa kebaikan daripada kekerasan, maka ia layak diperjuangkan.

\section{Peran Faktor Psikologis Dalam Permusuhan}

Dua faktor psikologis yang berperan besar dalam terciptanya permusuhan, baik antar individu, kelompok, etnis, maupun kepentingan adalah prasangka dan diskriminasi (Baron \& Byrne, 2003). Prasangka adalah sebuah skap (yang biasanya negatif) terhadap anggota kelompok tertentu, semata berdasarkan keanggotaan mereka dalam kelompok tersebut. Berprasangka buruk terhadap etnis tertentu, curiga terhadap kepentingan kelompok tertentu, ataupun tidak senang dengan seseorang karena ia adalah bagian dari kaum pendatang atau kaum lokal, semuanya adalah prasangka. Sedangkan diskriminasi adalah perilaku maupun aksi negatif terhadap kelompok yang menjadi sasaran prasangka. Perilaku ini dapat berupa kekerasan fisik yang dilakukan karena seseorang adalah bagian dari kelompok tertentu, cibiran-cibiran verbal karena seseorang adalah bagian dari etnis tertentu, ataupun tindak pengucilan terhadap mereka. 
Ada dua alasan mengapa manusia memiliki dan memelihara prasangka terhadap kelompok tertentu. Yang pertama, adalah karena dengan melakukannya maka mereka meningkatkan citra diri mereka sendiri. Dengan memandang rendah dan negatif sebuah kelompok, mereka akan merasa lebih superior. Dengan kata lain, prasangka memainkan sebuah peran penting untuk melindungi atau meningkatkan konsep diri mereka. Yang kedua, dengan adanya prasangka maka manusia tidak perlu repot-repot berpikir panjang karena merasa tahu seperti apakah orang itu sebenarnya, meskipun sebelumnya mereka tidak pernah bertemu dan tidak pernah saling mengenal. Kedua alasan itu, memelihara perasaan superioritas dan menghemat usaha untuk berpikir panjang, merupakan alasan utama mengapa prasangka begitu mudah muncul, terlebih dalam kondisi ekonomi yang sulit dan serba terbatas.

Karena tindakan-tindakan yang bersifat menyerang dalam diskriminasi berasal dari prasangka, maka mengetahui sebab kemunculan prasangka dapat memberi informasi yang sangat berharga bagi para pendidik untuk merancang program-program yang dapat meruntuhkan prasangka.

\section{Sumber Prasangka}

Setidaknya ada lima sumber utama yang dapat memunculkan prasangka (Baron \& Byrne, 2003). Kelima pemicu prasangka tersebut antara lain:

1. Kompetisi

2. Pembelajaran Sosial

3. Kategorisasi Sosial

4. Stereotip

5. Ilusi Kaum Minoritas

Kompetisi merupakan salah satu pemicu utama munculnya prasangka. Ketika sekelompok anak dihadapkan pada kompetisi untuk memperebutkan sebuah hadiah, maka hubungan antar kedua kelompok sangat mudah menjadi tegang. Masing-masing kelompok biasanya akan saling membanggakan kelompoknya dan mencari kelemahan juga kekurangan kelompok lain, terlebih jika yang dipertaruhkan adalah harga diri kelompok. Masing-masing kelompok akan memandang positif kelompoknya dan memandang kelompok lain secara lebih negatif. Dalam beberapa penelitian, prasangka ini akan runtuh ketika kelompok-kelompok yang bertikai dihadapkan pada tujuan yang hanya dapat dicapai bila mereka bersatu dan saling bekerja sama (superordinate goals). Ketika 
anak-anak dalam kelompok yang bertikai harus memperbaiki sebuah truk yang rusak secara bersama-sama, mengumpulkan uang mereka untuk menyewa film yang ada di tangan peneliti, atau aktivitas lain yang hanya dapat diwujudkan apabila mereka bersatu, maka ketegangan di antara kedua kelompok secara umum akan hilang dan terjalin persahabatan di antara kelompok.

Pembelajaran sosial adalah sebutan bagi kemampuan manusia untuk belajar dari pengalaman orang lain, meskipun dia tidak pernah mengalami hal yang sama secara langsung. Manusia bisa memandang orang dari etnik tertentu memiliki tabiat yang tidak baik karena mereka mendengar cerita-cerita dari orang tua, teman, guru, dan orang lainnya, padahal belum tentu orang tersebut memiliki tabiat seburuk itu. Lebih dari itu, mereka akan mendapat persetujuan dan dukungan jika memiliki sikap yang sama. Sebaliknya, jika mereka tidak memiliki sikap yang sama, maka mereka akan dimarah, ditentang, direndahkan, bahkan dikucilkan. Pengalaman berinteraksi langsung juga berpengaruh signifikan. Meskipun orang-orang sekitar memandang buruk tabiat seseorang dari etnik tertentu, kita akan cenderung tidak akan langsung menghakimi jika interaksi yang selama ini kita alami dengannya selama ini menyenangkan. Dari penelitian yang telah dilakukan, hasil pembelajaran sosial ini juga dapat diruntuhkan dengan dua jalan. Yang pertama adalah mendengar penerimaan dan ceritacerita positif dari orang-orang yang kita anggap penting dan kita hargai tentang orang yang kita kenakan prasangka, sedangkan yang kedua adalah mengalami sendiri rangkaian interaksi yang positif dan menyenangkan dengan orang yang selama ini kita kenakan prasangka.

Kategorisasi sosial merupakan faktor ketiga yang dapat memicu prasangka. Disebut kategorisasi sosial karena kita umumnya membagi dunia sosial dalam dua kategori yang berbeda, yaitu "kita" dan "mereka". Pembagian ini bisa terjadi pada banyak dimensi seperti ras, agama, jenis kelamin, usia, latar belakang etnis, pekerjaan, dan pendapatan. Jika kita kaya, maka yang miskin biasanya kita sebut sebagai mereka. Jika kita wanita, maka yang laki-laki biasanya kita sebut sebagai mereka. Sayangnya, para ahli psikologi sosial membuktikan bahwa "kita" seringkali dianggap lebih baik, sementara "mereka" seringkali dianggap lebih negatif. Jika kita miskin, maka ada saja hal-hal jelek yang terlihat dari orang-orang kaya, dan demikian pula sebaliknya. Dan yang lebih aneh lagi, "mereka" seringkali dianggap sama saja, sama buruknya, tidak ada bedanya. Etnis "mereka" biasanya sama saja, dan etnis "kita" belum tentu demikian. Fenomena ini dikenal dengan nama self-serving bias, atau 
memuliakan kelompok sendiri. Kabar baiknya, penelitian juga membuktikan bahwa prasangka dapat runtuh jika "kita" mulai memandang "mereka" sebagai bagian dari "kita", dan mulai mencoba untuk melihat banyaknya persamaan yang ada antara "kita" dan "mereka", atau dengan kata lain mencoba membuka mata untuk menerima bahwa "kita" dan "mereka" sebenarnya banyak persamaannya.

Picu prasangka yang keempat adalah stereotip, atau kerangka pikir yang terdiri dari pengetahuan dan keyakinan tentang kelompok sosial tertentu serta sifat dan karakter yang mungkin dimiliki oleh orang yang menjadi anggota kelompok ini. Stereotip menganggap semua orang dari kelompok tertentu memiliki tabiat yang sama, setidaknya pada derajat tertentu. Stereotip dapat dipicu oleh pembelajaran sosial yang telah dijelaskan di atas. Tidak seperti prasangka yang ditimbulkan oleh pembelajaran sosial, prasangka yang ditimbulkan oleh stereotip lebih sulit dirubah. Ketika kita bertemu dengan seseorang dari etnis yang tidak kita sukai karena adanya stereotip tertentu pada kelompoknya, maka stereotip itu cenderung tidak berubah meskipun perilaku orang tersebut tidak sesuai dengan stereotip kelompoknya. Kemungkinan pertama, orang itu cenderung akan dianggap berbeda dari kelompoknya atau masuk dalam kategori khusus. Sedangkan kemungkinan kedua, kita akan cenderung mengubah arti perilakunya sehingga konsisten dengan stereotipnya. Dengan kata lain, sebaik apapun perilaku orang tersebut, tetap saja akan dianggap buruk atau bermaksud buruk. Meskipun stereotip lebih sulit untuk dirubah, namun penelitian membuktikan bahwa manusia dapat dilatih untuk menolak dan berkata "tidak benar" pada stereotip tertentu.

Picu kelima adalah aspek minoritas. Dibuktikan dalam penelitian bahwa kaum minoritas akan lebih banyak mendapat perhatian jika melakukan kesalahan dibandingkan kaum mayoritas, seperti halnya sesuatu yang khas akan lebih mudah untuk diperhatikan dan diingat.

\section{Peace Education}

Peace education merupakan sebutan bagi program pendidikan yang didesain untuk merubah orientasi pemikiran bagi pihak-pihak yang sedang bertikai di daerah-daerah rawan konflik, agar mereka dapat saling mengenal dan menerima satu sama lain. Karena permusuhan berasal dari pikiran manusia, maka disitulah orientasi perdamaian semestinya dibangun. Untuk merubah orientasi pemikiran pihak-pihak tersebut, pendidikan memegang peranan penting. 
Dari sisi peserta pendidikan, umumnya mereka dibagi menjadi empat golongan (Halpérin, 1997), yaitu:

1. Anak-anak (13-17 tahun)

2. Remaja (17 tahun)

3. Guru

4. Kelompok profesional tertentu (pengacara, pekerja sosial, dan lain-lain)

Sebagai gambaran, berikut adalah model yang dapat dikembangkan untuk melaksanakan peace education, yang diadaptasi dari Kremer-Hayon dalam Halpérin, 1997:

Gambar: Elemen dasar dalam perencanaan proyek: sebuah kerangka konseptual

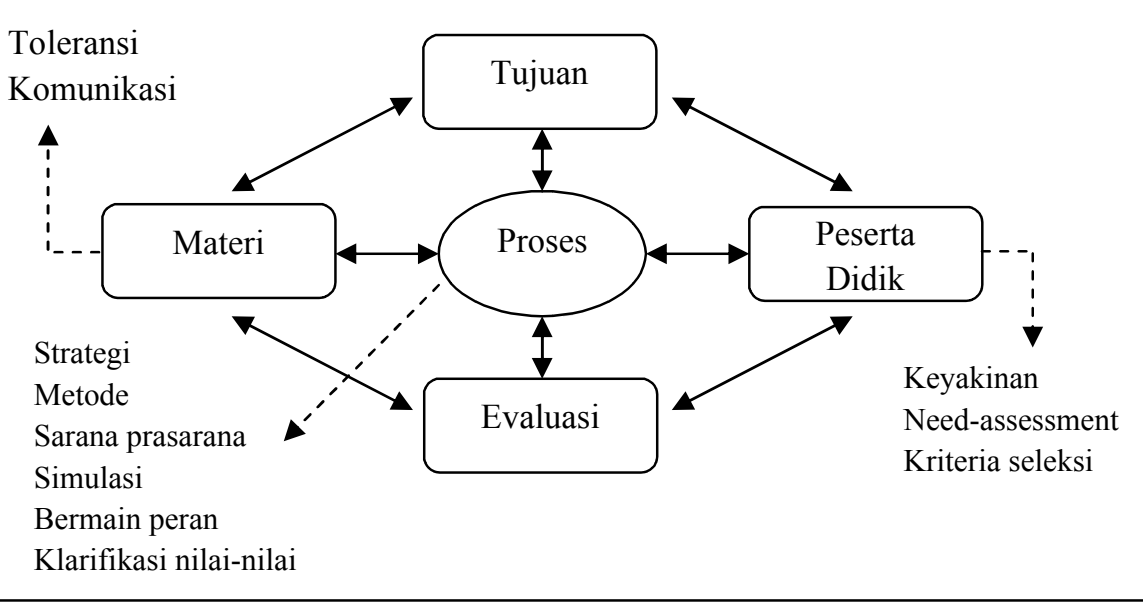

\section{Tujuan}

Karena tujuan dari peace education atalah merubah sikap dan perilaku, strategi yang relevan untuk perubahan perlu diterapkan. Faktorfaktor yang perlu dirubah meliputi tiga hal, yaitu kognitif, afeksidisposisional, dan perilaku. Ketiganya harus diperhatikan jika tujuannya adalah perubahan yang berarti dan tahan lama. Sebagai contoh, ketiga tujuan dapat diilustrasikan sebagai berikut:

1. Tujuan kognitif: "Memiliki pengetahuan dasar dan pemahaman tentang budaya, sejarah, dan kondisi lingkungan sekitar" 
2. Tujuan afektif-disposisional: "Mengembangkan kesediaan untuk bekerjasama dengan anggota kelompok lain, menerima mereka tanpa menghakimi perbedaan diantara kelompok, dan mengurangi stereotip"

3. Tujuan perilaku: "Berpartisipasi secara damai dan konstruktif dalam sebuah diskusi yang penuh dengan konflik dan stres, serta mencari jalan untuk mengurangi hambatan tanpa kekerasan fisik maupun psikis.

\section{Materi}

Materi pembelajaran disesuaikan dengan tujuan yang ingin dicapai. Beberapa materi yang mungkin dapat dipertimbangkan untuk dimasukkan adalah pengetahuan tentang kondisi sosial dan lingkungan, pengetahuan tentang budaya kelompok lain, mempelajari bahasa kelompok lain, dan lain sebagainya. Materi sebaiknya disesuaikan dengan karakteristik peserta didik, termasuk usia dan latar belakang sosial. Meskipun materi adalah hal yang penting, namun ia bukan satu-satunya faktor penentu yang akan membantu tercapainya tujuan pembelajaran. Proses belajar-mengajar yang terjadilah yang justru akan membawa perubahan yang diinginkan.

\section{Peserta Didik}

Kegagalan dalam memahami minat dan kebutuhan peserta didik adalah hambatan utama dalam intervensi pendidikan. Karakter spesifik dari kelompok peserta didik dan perbedaan individual diantara mereka harus dikenali dengan baik.

\section{Proses}

Membicarakan proses sama halnya dengan membicarakan metode dan cara-cara yang ditempuh untuk meraih tujuan pembelajaran. Metode dan cara yang ditempuh harus melibatkan komponen kognitif, afeksidisposisional, dan juga perilaku. Membaca, debat, dan diskusi adalah bentuk aktivitas yang menekankan kemampuan intelektual dan refleksi, bagian dari aspek kognitif. Klarifikasi nilai-nilai sosial dan bermain peran mewakili komponen afeksi-disposisional. Sedangkan mendengarkan, memberikan solusi konstruktif dalam permasalahan-permasalahan yang penuh konflik, dan mengekpresikan toleransi terhadap ide-ide yang saling kontradiktif mewakili aspek perilaku. 


\section{Evaluasi}

Metode kualitatif dan kuantitatif dalam evaluasi akan saling mendukung satu sama lain, dan memberikan bentuk masukan yang bervariasi berdasarkan tes tertulis, diskusi, wawancara, observasi, dan portofolio. Model yang telah disajikan dapat memberikan rangkaian pertanyaan yang tersistematisasi untuk dipertimbangkan dalam rangkaian kerja selanjutnya. Sebagai contoh, ketika gagal, evaluator akan memberikan rangkaian pertanyaan. Apakah tujuan pembelajaran terlalu tinggi? Apakah tujuan pembelajaran tidak cocok dengan kelompok peserta didik yang sedang ditangani? Apakah materi pembelajaran telah didesain dengan baik? Sejauh mana proses belajar mengajar diaplikasikan dengan benar? Pertanyaan-pertanyaan tersebut dapat dikaji untuk mencapai kesuksesan pembelajaran dalam rangkaian kerja selanjutnya.

\section{Urgensi Penerapan Peace Education di Kalimantan Barat}

Secara Nasional, Lembaga Survey Indonesia pernah menyatakan bahwa kepercayaan sosial (social trust) bangsa Indonesia terhadap sesamanya terbilang rendah. Dalam survey yang melibatkan 1200 orang yang sudah memiliki hak pilih dari 33 provinsi berbeda, tercatat bahwa sebanyak $48 \%$ masyarakat merasa keberatan jika penganut agama lain mengadakan acara keagamaan di dekat rumahnya, dan 42,3\% masyarakat merasa keberatan jika penganut agama lain mendirikan tempat ibadah di sekitar rumahnya. Berikut data lengkap yang dimuat dalam Kompas (2006):

\section{DIMENSI SOSIAL KEAGAMAAN}

Keberatankah jika penganut agama lain mengadakan acara keagamaan di dekat rumah Anda? (\%)

Keberatan 36,7

Tidak keberatan 48

Tergantung 11,9

Tidak tahu/tidak menjawab 3,4

Setujukah jika penganut agama lain mendirikan tempat ibadah di sekitar rumah Anda? (\%)

Keberatan 42,3

Tidak keberatan 38,1

Tergantung 15

Tidak tahu/tidak menjawab 4,6
Persentase dukungan terhadap organisasi Islam (\%)

Jaringan Islam Liberal (JIL) 2,5

Hizbut Tahrir 3,3

Majelis Mujahidin Indonesia (MMI) 11

Front Pembela Islam (FPI) 16,9

Majelis Ulama Indonesia (MUI) 59,1

Nahdlatul Ulama (NU) 71,7

DIMENSI SOSIAL-POLITIK

Di antara kelompok masyarakat di bawah ini, mana yang paling tidak

Anda sukai? (\%)

Buddha 0,4

Hindu 0,4

Cina 0,5

Katolik 0,8

Kristen Protestan 1,7 
Yahudi 3,9

Anggota DI/TII 0,5

Komunis/PKI 62,7

Kelompok lain 0,7

Tidak menjawab 4,2

Tidak ada 24,1

Apakah kebudayaan Barat lebih banyak membawa keburukan bagi umat Islam di Indonesia? (\%)

Setuju 61,3

Tidak setuju 22,4

Tidak punya sikap 5,6

Tidak menjawab 10,7

Apakah Anda setuju dengan pendapat bahwa umat Islam di seluruh dunia sering diperlakukan tidak adil oleh umat lain? (\%)

Sangat Setuju 4,9

Setuju 32,5

Tidak setuju 38,8

Tidak punya sikap 4,9

Tidak tahu/Tidak menjawab 18,9

\section{METODOLOGI SURVEI}

Populasi survei adalah warga negara Indonesia yang punya hak pilih dalam pemilihan umum (berusia 17 tahun atau lebih atau sudah menikah). Jumlah sampel 1.200 orang, dengan toleransi kesalahan $+2,9$ persen. Sampel berasal dari 33 provinsi yang dipilih secara proporsional terhadap populasi. Quality control terhadap wawancara dilakukan secara random sebesar 20 persen.

Responden terpilih (spot check) didatangi kembali oleh supervisor, tidak ditemukan kesalahan berarti. Survei berlangsung 23-27 Januari 2006.

Keragaman responden yang disurvei tak jauh beda dengan keragaman masyarakat Indonesia seperti dalam survei Biro Pusat Statistik. 
Kalimantan Barat sendiri dapat disebut sebagai daerah dengan potensi konflik yang tinggi. Kompas (2006) menggolongkan Kalimantan Barat sebagai satu dari 20 daerah rawan konflik di Indonesia, dengan pemicu utama berupa masalah etnik, akses dan kontrol terhadap hasil alam, serta konflik antara kelompok lokal dan kelompok pendatang. Konflik berdarah dalam skala besar antar tiga etnis berbeda di Kalimantan Barat terjadi pada tahun 1997 dan 1999. Konflik kekerasan terus berlanjut hingga tahun 2002 di wilayah Kodya dan Kabupaten Pontianak. Selain itu, ada juga yang mencatat bahwa telah terjadi konflik antar etnis Dayak dan Madura sebanyak 12 kali sepanjang tahun 1950 hingga 1999. Pada tahun 1967, pernah pula terjadi konflik antara etnis Tionghoa dan Dayak terkait dengan usaha pertambangan emas di Kalimantan Barat yang berujung pada pengusiran besar-besaran warga Tionghoa keluar dari wilayah pedalaman (Supriyadi, 2008).

Konflik berdarah yang tercatat di atas adalah konflik besar dengan kerugian material maupun imaterial yang tidak sedikit, belum termasuk berbagai konflik kecil yang sulit untuk dicatat.

Dengan tipisnya rasa kebersamaan yang tercermin dari rangkaian peristiwa di atas, daerah rawan konflik diibaratkan seperti rumput kering yang mudah terbakar, karena konflik besar-besaran dapat dipicu hanya dari perselisihan kecil. Kebencian dan kecurigaan berbasis agama, etnik, dan kesenjangan sosial ada dimana-mana dan semakin didengungkan. Benih itu bahkan telah mulai ditebar sejak anak masih sekolah ketika orang-tua berusaha untuk melindungi anaknya dari pengaruh orang-orang dari agama atau suku tertentu, dan ketika kelompok tertentu berusaha untuk melindungi anggotanya dari pengaruh kelompok lain.

Dalam keadaan rawan konflik seperti ini, pembentukan budaya perdamaian tidak dapat terwujud hanya dengan bentuk sosialisasi saja. Perlu adanya upaya sistematis mulai dari pembinaan anak usia dini hingga dewasa agar memiliki prinsip sadar perdamaian. Pendidik mempunyai peran penting untuk mengasah sikap maupun perilaku tertentu di kalangan siswa didik, dan melatih mereka agar konflik yang muncul tidak diselesaikan dengan jalan kekerasan, melainkan dengan jalan dialog yang dilandasi oleh semangat untuk saling menghargai hak dan martabat masing-masing.

\section{Penutup}

Demikianlah rangkaian informasi yang diharapkan dapat membantu pengembangan peace education di Kalimantan Barat pada masa 
yang akan datang. Sumber permasalahan konflik antar kelompok yang dapat digunakan untuk mengidentifikasi sasaran intervensi, serta model pendidikan yang dapat dipergunakan sebagai panduan pelaksanaan, keduanya telah disajikan seringkas dan sesederhana mungkin. Semoga tulisan ini dapat digunakan sebagaimana mestinya.

\section{Daftar Bacaan}

. 2006. Toleransi yang Mengkhawatirkan. Kompas No. 25/XXXV/14 - 20 Agustus 2006. . 2006. Negeri Seribu Konflik. Kompas No. 25/XXXV/14 - 20 Agustus 2006.

Baron, R. A., Byrne, D. 2003. Social Psychology $10^{\text {th }}$ ed. New Jersey: Pearson Education. Inc.

Blumberg, H. H., Hare, A. P., Costin, A. 2006. Peace Psychology: A Comprehensive Introduction. New York: Cambridge University Press

Halpérin, D. S. 1997. Shaping New Attitudes to Peace Through Education. Bellegarde: SADAG.

Supriyadi, Yohaness. 2008. Tentang Konflik di Kalbar. http://yohanessupriyadi.blogspot.com/2008/03/tentang-konflik-dikalbar.html 2008. Diakses pada 26/04/2008, 17:40 WIB 